\title{
Chromatin in fractal globule state: evidence from comet assay
}

\author{
K. S. Afanasieva, M. I. Chopei, A. V. Sivolob \\ Educational and Scientific Center «Institute of Biology», \\ Taras Shevchenko National University of Kyiv \\ 64/13, Volodymyrska Str., Kyiv, Ukraine, 01601 \\ aphon@ukr.net
}

\begin{abstract}
At higher order levels chromatin is organized into loops that appear as a result of contacts between distant loci. The aim of this work was to investigate the length distribution of the DNA loops in nucleoids obtained after lysis of either whole cells or isolated cell nuclei. Methods. We used single cell gel electrophoresis to analyze the kinetics of the DNA loop migration from the two nucleoid types. Results. The kinetics of the DNA exit was found to have specific features for the two types of nucleoids. At the same time, in both cases, the DNA amount in the electrophoretic track depends linearly on the length of the longest loops in the track. Conclusions. We have concluded that for the loops up to $\sim 100 \mathrm{~kb}$ the length distribution appears to be consistent with the fractal globule organization.
\end{abstract}

Keyw or d s: DNA loop, fractal globule, comet assay, cell nuclei.

\section{Introduction}

In eukaryotic cell DNA is organized into multimolecular complex known as chromatin, the spatial organization of which plays an important role in different cellular processes: from gene expression to DNA replication and repair [1-3]. Despite the comprehensive understanding of the chromatin structure at low levels (e.g. nucleosome) the higher order structural levels remain not completely understood. In recent years several methods have been developed to analyze three-dimensional architecture of the interphase nucleus. An important progress in this field has been made due to the chromosome conformation capture technique (3C) and especially due to its highthroughput modification - Hi-C technique, which allows the mapping of interactions between distant chromatin loci [4-6]. The analysis of genome-wide interaction maps revealed that at least at megabase scale resolution the chromatin conformation is consistent with a fractal globule organization $[4,7]$. The fractal globule is a compact polymer state, which is different from more familiar equilibrium globule in two respects. First, in contrast to the equilibrium globule, the fractal globule is characterized by the absence of knots. The second feature of the fractal globule is that the probability of contacts between distant loci is directly inversely proportional to the contour distance [8-10].

Some of these contacts may be preserved to give chromatin loops: it was shown that the formation of loops can be accomplished on the basis of diffusion driven collisions of distant loci and entropy driven crowding $[11,12]$. The mechanisms of the loop long time stabilization are very diverse. Chromatin loops may be stabilized as a result of transcription activation or repression that involves enhancer promoter interactions [13], interactions between insulators [14], formation of polycomb bodies [15], and transcription factories [16]. Additionally, looping may arise from the constitutive interaction between DNA sites and protein filaments of nuclear lamina or other subnuclear structures $[17,18]$. Finally, recent results obtained using high-resolution $\mathrm{Hi}-\mathrm{C}$ technique,

\footnotetext{
(C) 2015 K. S. Afanasieva et al.; Published by the Institute of Molecular Biology and Genetics, NAS of Ukraine on behalf of Biopolymers and Cell. This is an Open Access article distributed under the terms of the Creative Commons Attribution License (http://creativecommons.org/licenses/by/4.0/), which permits unrestricted reuse, distribution, and reproduction in any medium, provided the original work is properly cited
} 
the so-called in situ $\mathrm{Hi}-\mathrm{C}$, argue that approximately 10000 chromatin loops are anchored by the CTCF transcription factor and the cohesin subunits RAD21 and SMC3 [6]. The diversity of ways for the chromatin loop formation results in the diversity of the loops itself: their number and size distribution may depend on the cell type, the functional state, the phase of the cell cycle $[2,19]$.

In our previous works we have shown that single cell gel electrophoresis (or the comet assay) is an approach which may be applied to study the DNA looping $[20,21]$. The method is based on the analysis of electrophoretic migration of DNA from nucleoids the structures that are produced after cell lysis in agarose blocks in the presence of detergents and high ionic strength [22-24]. Such nucleoids have been known for a long time to contain nothing but negatively supercoiled DNA loops attached to some residual protein structures $[22,25]$. Our results [20,21] have supported this view. During electrophoresis the nucleoid loops extended toward the anode to form an electrophoretic track (the comet tail). Certainly, only some part of the most stable loops remains in the nucleoids after cell lysis. However, since these loops preexisted in vivo, the nucleoids can be viewed as «ghosts» which keep some characteristics of the loop domain organization in the cell nuclei.

Applying the kinetic approach to analyze the DNA loop migration we have found the rate of the loop migration to be sensitive to the supercoiling level $[20,21,26]$. We also determined several important characteristics of the loop domain organization: (i) the fraction of loops that migrate at different time of electrophoresis and their size; (ii) the initial supercoiling level in the loops; (iii) the peculiarities of DNA-protein interaction at the loop anchor points $[20,21,26]$. Additionally, some differences in the kinetics of the loop migration were demonstrated for the two types of nucleoids: obtained after a lysis of either whole cells (cell-derived nucleoids) or isolated cell nuclei (nuclei-derived nucleoids) [27]. It has been argued that the kinetic behavior is different due to agarose penetration into nuclei (but not into cells) before polymerization of the agarose gel.
This article is focused on the length distribution of the DNA loops in the comet tail of the cell-derived and nuclei-derived nucleoids. We have found that for the loops up to $\sim 100 \mathrm{~kb}$ the length distribution appears to be consistent with the fractal globule organization. This observation points out that the fractal globule model is valid not only at the megabase scale (as it has been shown by the Hi-C technique) but also at the scale of several tens of kilobases.

\section{Materials and Methods}

\section{Sample preparation}

Human peripheral blood from 3-5 healthy donors was collected into heparinized medical syringe by fingerpricking. Lymphocytes were separated by centrifugation in a density gradient (Histopaque 1077, Sigma, USA) according to instructions of the manufacturer. Cells then were washed in $0.15 \mathrm{M} \mathrm{NaCl}$ twice and used either to prepare microscope slides or to isolate nuclei. Before nuclei isolation lymphocytes were washed twice in STMK buffer $(0.25 \mathrm{M}$ sucrose, $50 \mathrm{mM}$ Tris- $\mathrm{HCl}, 5 \mathrm{mM} \mathrm{MgCl}, 25 \mathrm{mM} \mathrm{KCl}, 0.5 \mathrm{mM}$ EDTA, 0.5 mM EGTA, pH 7.4). Then the cell suspension in STMK buffer $(2.5 \mathrm{ml})$ was layered on $1.5 \mathrm{ml}$ of the same buffer containing $2.1 \mathrm{M}$ sucrose and centrifuged $90 \mathrm{~min}$ at $19000 \mathrm{~g}, 4{ }^{\circ} \mathrm{C}$. The purity of the isolated nuclear fraction was checked by Western blot analysis using antibodies against histone $\mathrm{H} 1$ and $\alpha$-tubulin as specific markers of nuclear and cytoplasmic fractions respectively. Isolated nuclei were washed by STMK buffer twice and immediately used for slide preparation.

\section{The comet assay}

Cells or nuclei were embedded in the $0.67 \%$ agarose gel (low-melting point agarose, Sigma, USA) on the surface of a microscope slide. Slides were treated with ice-cold lysis solution $(2.5 \mathrm{M} \mathrm{NaCl}$, 100 mM EDTA, 10 mM Tris- $\mathrm{HCl}$ (pH 8.0), $1 \%$ Triton X-100 (Ferak, Germany)) for several hours. After the lysis slides were washed twice by TBE buffer ( 89 mM Tris-borat, 2 mM EDTA, pH 7.5) and electrophoresed $(1 \mathrm{~V} / \mathrm{cm}, 300 \mathrm{~mA})$ in the same buffer in dark at $4{ }^{\circ} \mathrm{C}$. Several slides, which were 
simultaneously prepared in the same way, were placed into the electrophoresis tank, and then they were taken out every $10 \mathrm{~min}$ of electrophoresis. After electrophoresis slides were stained with $1.3 \mu \mathrm{g} / \mathrm{ml}$ of DAPI (4',6-diamidino-2-phenylindole, Sigma, USA) and immediately analyzed with a fluorescent microscope (LOMO, Russia) connected with a camera Canon EOS 1000 D. A total 100-150 randomly chosen nucleoids on each slide were examined using image analysis software CometScore (TriTec, USA) to determine the relative amount of DNA in the tails and the tail length. The relative amount of DNA in the tail was determined as the ratio of the tail fluorescence intensity to the total intensity of the comet. The tail length was defined as the distance from the center of mass of the comet head to the distal end of the tail. The length of the comet tail reflects the contour length of the longest loops in the tail. Taking the contour length of the loop to be roughly two times longer than the extended loop, the tail length was multiplied by two and divided by $0.34 \mathrm{~nm}$ (the distance between the adjacent base pairs) to convert it in the contour length (in base pairs) of the longest loops.

\section{Analysis of the comet assay data}

Kinetic plots (the relative amount of DNA in the tail $f$ versus electrophoresis time $t$ ) obtained for the nuclei-derived nucleoids were fitted with the standard equation of monomolecular kinetics:

$$
f=A(1-\exp (k t)),
$$

where $A$ is the maximum relative amount of DNA that can exit, $k$ is the rate constant. The two-step plots obtained for cell-derived nucleoids were fitted as described [21] with the equation:

$$
\mathrm{f}=\mathrm{A}_{1}\left(1-\exp \left(\mathrm{k}_{1} \mathrm{t}\right)\right)+\frac{\mathrm{A}_{2}}{1+\exp \left(\mathrm{k}_{2}\left(\mathrm{t}_{0}-\mathrm{t}\right)\right)},
$$

where $A_{1}$ and $A_{2}$ are the maximum amplitudes of the two components, $k_{1}$ and $k_{2}$ are the rate constants, and $t_{0}$ is the transition half-time. The first term in Eq. (2) describes the first rapid phase of the DNA exit, the second term, which obeys the sigmoidal Boltzmann equation, corresponds to the slow sigmoid phase.
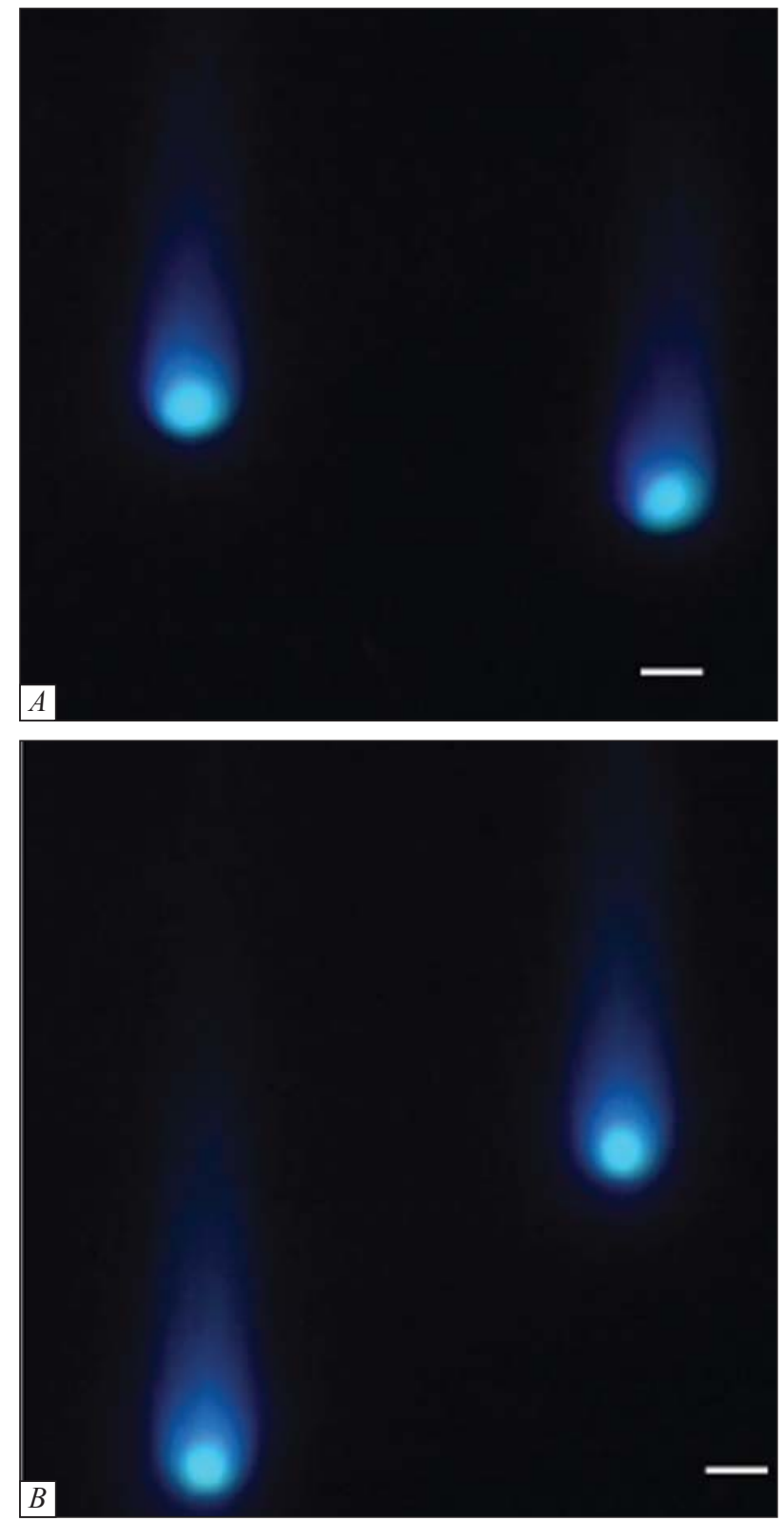

Fig. 1. Representative examples of comet images obtained after 60 min of electrophoresis of nucleoids prepared from cells $(A)$ and nuclei $(B)$. Bars correspond to $10 \mu \mathrm{m}$

The two parameters, the fraction $f$ of DNA in the tail (at a given time) and the contour length $s_{m}$ of the longest loops in the tail, are related by the equation [21]:

$$
f=\lambda \int_{0}^{s_{m}} s p_{s} d s
$$



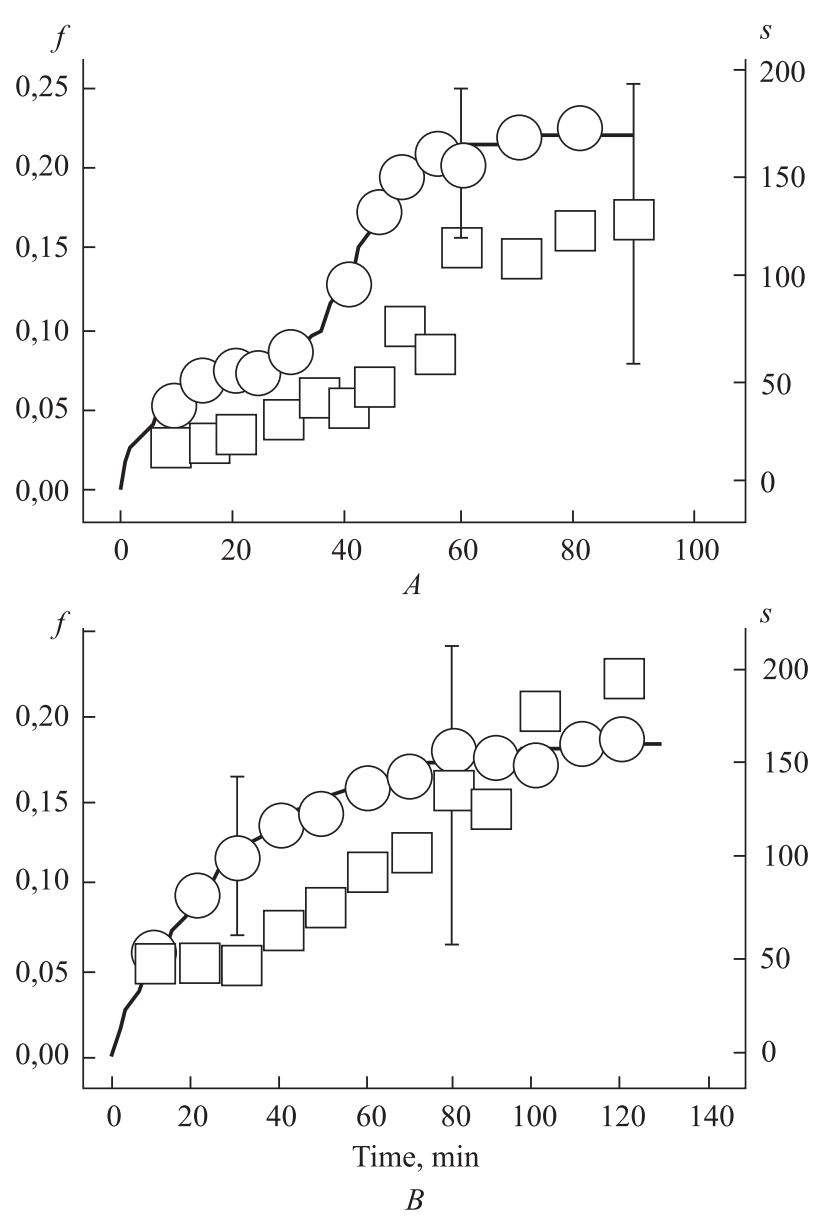

Fig. 2. The average relative amount of DNA in the tails $(f, \circ)$ and the average contour length of the longest loops in the tails $(s, \square)$ as functions of electrophoresis duration for nucleoids prepared from cells $(A)$ and from isolated nuclei $(B)$. Each point is an average for 5 to 10 independent experiments. Error bars represent the maximum standard deviations; continuous curves are obtained by fitting as described in the Materials and methods

where $\lambda$ is a coefficient, $s$ is the loop contour length, $p_{s}$ is the fraction (or the probability) of loops of the size $s$ present in the tail at a given time. Eq. (3) was used to analyze the experimental dependence of $f$ on $s_{m}$.

\section{Results and Discussion}

The typical images of comets obtained after electrophoresis of nucleoids prepared from nuclei and cells are presented in Fig. 1: the appearance of the comets is about the same in the two cases. Fig. 2 shows the kinetics of DNA exit from intact non-damaged cell- derived nucleoids $(A)$ and nuclei-derived nucleoids $(B)$ along with the time dependent change in the average contour length of the longest loops in the comet tails. Evidently, the DNA loop migration has specific features in the two cases.

The most significant difference related to the shape of the kinetic plots of the DNA amount in the comet tails: in contrast to cell-derived nucleoids, the stepwise behavior was not observed for nuclei-derived nucleoids and the dependence of the relative amount of DNA in the tails on time was not sigmoid. In our previous work [27] we have explained this difference by peculiarities of the nucleoid microenvironments for these two types of material. The reason is a probable agarose penetration into the nuclei, but not into cells, before polymerization of the agarose gel. As a result, the medium inside the nucleoid head is made by agarose and DNA, with agarose creating a constant friction for the loop movement. This is in contrast to the cell-derived nucleoids, where the friction, which is made by DNA only, changes during electrophoresis due to the DNA exit into the tail thus creating a cooperative effect [27].

Additionally, there are the following small differences between the two nucleoid types. First, in the case of nuclei-derived nucleoids, as compared to the nucleoids obtained from the whole cells, the contour length of the longest loops in the comet tails tends to be slightly higher at the initial stage of electrophoresis (up to $40^{\text {th }}$ minute). Second, in contrast to the relative amount of DNA in the tails, which reaches the saturation level and then remains constant for both nucleoid types, the contour length of the longest loops in the comet tails reaches the saturation level during electrophoresis of the cell-derived nucleoids only. It is noteworthy that the fraction of the long loops in the comet tails is very small: their contribution is detectable for the comet tail length, but not for the relative amount of DNA in the tails. Both differences may be explained by somewhat different lysis efficacy. Indeed, the lysis is expected to be more effective for nuclei (which, during their isolation, are already depleted of cellular membranes and a vast majority of cellular proteins) than for whole cells. Thus, the larger loops can migrate more easily 
during electrophoresis of nuclei-derived nucleoids. It is not excluded also that some fragments of cytosceleton, which remain in the cell-derived nucleoids but not in the nuclei-derived ones, may contribute to additional hampering of DNA migration. However, the two small differences are almost within the experimental error (Fig. 2).

Despite the differences mentioned above, two parameters, the DNA amount in the tails and the tail lengths, change in parallel for both nucleoid types: they both increase with time. This simple observation suggests that the two parameters should be correlated with each other (Fig. 3). In our previous work we have found that for the cell-derived nucleoids the DNA amount in the tails depends linearly on the tail length [21]. Keeping in mind the distinct kinetic behaviors of DNA migration for the two nucleoid types, one could expect also some differences in the correlations between the DNA amount in the tails and the tail lengths. Fig. 3 shows this is not the case. Obviously, for the loop contour lengths in between $~ 20$ and $100 \mathrm{~kb}$, the correlations are perfectly linear for both nucleoid types. The linearity is disturbed for very long loops, the size of which is close to the limit of the gel resolution.

The dependence in Fig. 3 is, in fact, the cumulative probability for the loops below some size to be present in the nucleoid (and hence in the tail), which obeys Eq. (3). Since some of the contacts between distant loci give rise to the loops, the most stable of which (resistant to lysis conditions) remain in nucleoids and form the comet tail, the parameter $p_{s}$ in Eq. (3) is directly proportional to the probability of contacts between two sites separated by the contour distance $s$.

It is obvious from Eq. (3) that the DNA fraction in the comet tail $(f)$ may be directly proportional to the longest loop size $\left(s_{m}\right)$ in the case when $p_{s} \sim s^{-1}$ : then $p_{s}$ and $s$ under integral are canceled and we simply have $f=\lambda s_{m}$. The power-law scaling $p_{s} \sim s^{-1}$ corresponds to the so called fractal globule - a polymer state that appears as a result of a polymer condensation $[4,7,9]$. The fractal globule possesses several properties, the most important of which are that the polymer in this state is unknotted and that the probability of contacts between distant loci is directly
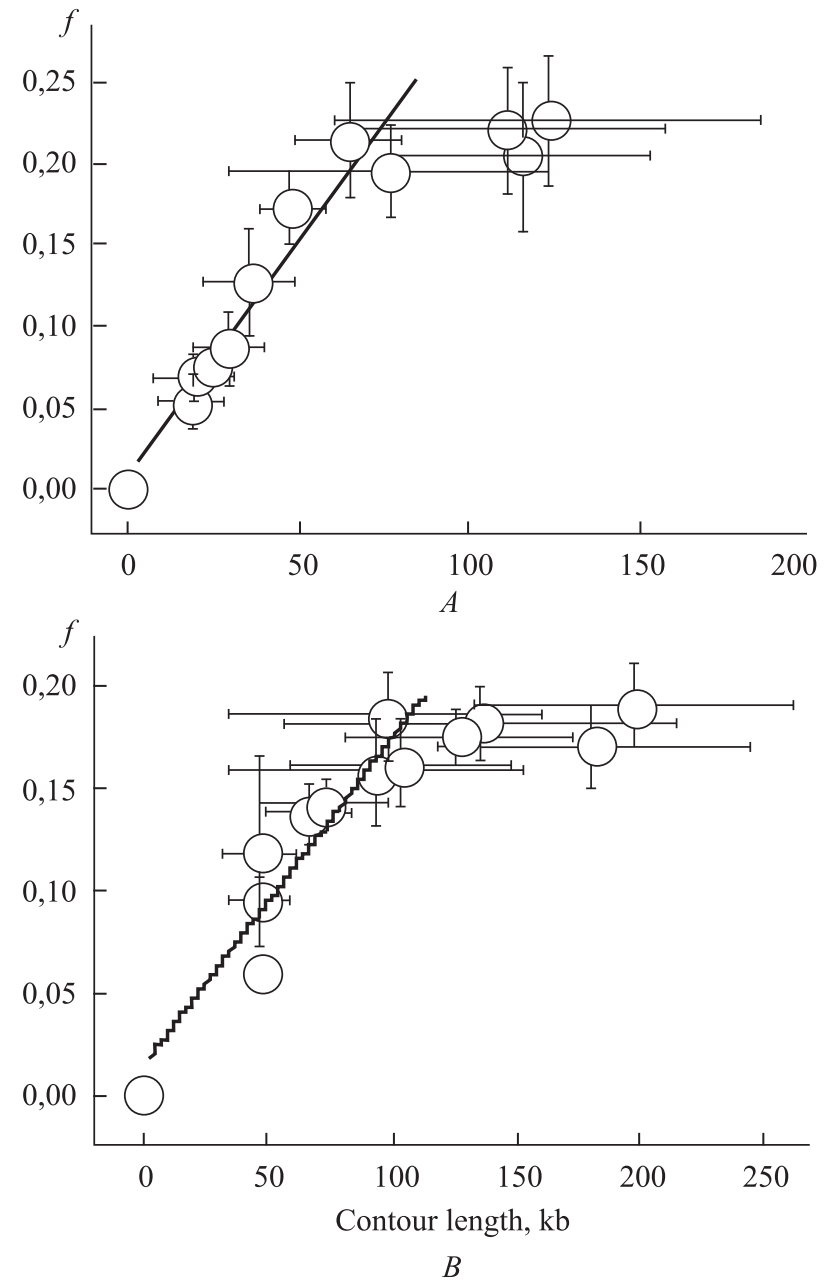

Fig. 3. Correlation between the average relative amount of DNA in the comet tails $(f)$ and the average contour length of the longest loops in the tail for cell-derived nucleoids $(A)$ and nuclei derived nucleoids $(B)$. Error bars represent the standard deviations

inversely proportional to the contour distance. This long-lived intermediate polymer state was introduced theoretically in 1988 [8], but has not been observed in experiments until 2009, when the first experimental evidences for the fractal globule state of interphase chromatin in cell nuclei were obtained using the Hi-C technique [7]. It was shown that the contact probability between two loci as a function of their distance is consistent with a fractal globule organization in the ranges of several megabases (between 0.7 and $7 \mathrm{Mb}$ ). At shorter distances (hundreds of kilobases) chromatin was shown to be organized 
in discrete subunits - topologically associating domains (TADs), and it was not clear whether the fractal globule organization persists at low scales [4, 7]. Our results confirm that, for both cells and isolated nuclei, the fractal globule remains valid for much shorter distances - at the scale of several tens of kilobases.

It should be mentioned that in our experiments the part of DNA, which was found to be able to migrate in the comet tails, is rather small: the saturation levels of the DNA exit were 0.22 in the case of cell-derived nucleoids and 0.19 in the case of nuclei-derived ones (the differences are within the experimental error). The simplest explanation of this limitation, discussed in [21], is related to the loop size: very long loops cannot exit and remain in the comet head even after prolonged electrophoresis. The increase in the loop size may occur as a result of cell lysis due to protein dissociation and/or perturbations in the DNA-protein interactions at the loop anchor points [21]. The question, which has been never answered, is how the anchors may remain in nucleoids after the treatment with $2.5 \mathrm{M} \mathrm{NaCl}$. Some insight may be provided due to a comparison of our results with the recent report on the mapping of $3 \mathrm{D}$ chromatin organization with kilobase resolution [6]. Applying high-resolution in situ Hi-C technique Rao et al. has identified 9448 loops ranged in size from $40 \mathrm{~kb}$ to $3 \mathrm{Mb}$ with median length $185 \mathrm{~kb}$. About $86 \%$ of these loops were anchored by two proteins, transcription factor CTCF and cohesin [6]. Taking $6.6 \cdot 10^{6} \mathrm{~kb}$ as the size of the diploid genome, the fraction of DNA in these loops $f$ $\approx 9448 \cdot 185 \cdot 0.86 / 6.6 \cdot 10^{6}=0.23$.

This value is quite comparable with the maximum relative amount of DNA in the tails that was observed at the saturation level in our experiments. This finding may point out that only the loops that were anchored in vivo by CTCF and cohesins remain in nucleoids after cell/nuclei lysis. Since the cohesin complex forms a large ring embracing two DNA strands without direct contact $[28,29]$, it is not surprising that only the loops anchored in this way resist the lysis treatment.

\section{Conclusions}

In this study we present the results of the comet assay applied to investigate the loop length distribu- tion in the comet tail of the two nucleoid types, obtained either from isolated cells or from isolated nuclei. Our results can be summarized as follows. (1) The kinetic behaviors of DNA migration are different for the two nucleoid types. The differences observed may originate from specific peculiarities of the nucleoid microenvironments and also by different lysis efficiency in the two cases. (2) The loop length distribution, in the range from 20 to $100 \mathrm{~kb}$, appears to be consistent with the fractal globule organization. Therefore, the fractal globule model can be valid not only at the scale of several megabases as it has been revealed using $\mathrm{Hi}-\mathrm{C}$ technique, but also at the scale of several tens of kilobases. (3) Our results, when compared with the recent data obtained by high-resolution Hi-C technique, allows us to suggest that the most stable chromatin loops which remain in nucleoids after cell/nuclei lysis are probably anchored by cohesins.

\section{REFERENCES}

1. Woodcock CL, Ghosh RP. Chromatin higher-order structure and dynamics. Cold Spring Harb Perspect Biol. 2010;2(5): a000596.

2. Kadauke S, Blobel GA. Chromatin loops in gene regulation. Biochim Biophys Acta. 2009;1789(1):17-25.

3. Wilson RH, Coverley D. Relationship between DNA replication and the nuclear matrix. Genes Cells. 2013;18(1):17-31.

4. Dekker J, Marti-Renom MA, Mirny LA. Exploring the threedimensional organization of genomes: interpreting chromatin interaction data. Nat Rev Genet. 2013;14(6):390-403.

5. Gibcus JH, Dekker J. The hierarchy of the 3D genome. Mol Cell. 2013;49(5):773-82.

6. Rao SS, Huntley MH, Durand NC, Stamenova EK, Bochkov ID, Robinson JT, Sanborn AL, Machol I, Omer AD, Lander $E S$, Aiden EL. A 3D map of the human genome at kilobase resolution reveals principles of chromatin looping. Cell. 2014;159(7):1665-80.

7. Lieberman-Aiden E, van Berkum NL, Williams L, Imakaev $M$, Ragoczy T, Telling A, Amit I, Lajoie BR, Sabo PJ, Dorschner MO, Sandstrom R, Bernstein B, Bender MA, Groudine $M$, Gnirke A, Stamatoyannopoulos J, Mirny LA, Lander ES, Dekker $J$. Comprehensive mapping of long-range interactions reveals folding principles of the human genome. Science. 2009;326(5950):289-93.

8. Grosberg AY, Nechaev SK, Shakhnovich EI. The role of topological constraints in the kinetics of collapse of macromolecules. J Phys France. 1988;49(12):2095-100.

9. Mirny LA. The fractal globule as a model of chromatin architecture in the cell. Chromosome Res. 2011;19(1):37-51. 
Chromatin in fractal globule state: evidence from comet assay

10. Fudenberg G, Mirny LA. Higher-order chromatin structure: bridging physics and biology. Curr Opin Genet Dev. 2012; 22(2):115-24.

11. Bohn $M$, Heermann $D W$. Diffusion-driven looping provides a consistent framework for chromatin organization. PLoS One. 2010;5(8):e12218.

12. Marenduzzo D, Micheletti C, Cook PR. Entropy-driven genome organization. Biophys J. 2006;90(10):3712-21.

13. Bulger M, Groudine M. Functional and mechanistic diversity of distal transcription enhancers. Cell. 2011;144(3):327-39.

14. Van Bortle K, Corces VG. Nuclear organization and genome function. Annu Rev Cell Dev Biol. 2012;28:163-87.

15. Sparmann A, van Lohuizen $M$. Polycomb silencers control cell fate, development and cancer. Nat Rev Cancer. 2006;6 (11):846-56.

16. Cook PR. A model for all genomes: the role of transcription factories. J Mol Biol. 2010;395(1):1-10.

17. Kind J, van Steensel B. Genome-nuclear lamina interactions and gene regulation. Curr Opin Cell Biol. 2010;22(3):320-5.

18. Cremer T, Cremer C. Chromosome territories, nuclear architecture and gene regulation in mammalian cells. Nat Rev Genet. 2001;2(4):292-301.

19. Vassetzky Y, Hair A, Méchali M. Rearrangement of chromatin domains during development in Xenopus. Genes Dev. 2000;14(12):1541-52.

20. Afanasieva K, Zazhytska M, Sivolob A. Kinetics of comet formation in single-cell gel electrophoresis: loops and fragments. Electrophoresis. 2010;31(3):512-9.

21. Afanasieva K, Chopei M, Zazhytska M, Vikhreva M, Sivolob $A$. DNA loop domain organization as revealed by single-cell gel electrophoresis. Biochim Biophys Acta. 2013;1833(12): 3237-44.

22. Ostling $O$, Johanson KJ. Microelectrophoretic study of radiation-induced DNA damages in individual mammalian cells. Biochem Biophys Res Commun. 1984;123(1):291-8.

23. Olive PL. The comet assay. An overview of techniques. Methods Mol Biol. 2002;203:179-94.

24. Collins AR. The comet assay for DNA damage and repair: principles, applications, and limitations. Mol Biotechnol. 2004; 26(3):249-61.

25. Cook PR, Brazell IA. Supercoils in human DNA. J Cell Sci. 1975;19(2):261-79.

26. Zazhytska MO, Afanasieva KS, Chopei MI, Vikhreva MA, Sivolob $A V$. Influence of chloroquine on kinetics of singlecell gel electrophoresis. Biopolym Cell. 2012;28(4):292-7

27. Afanasieva $K$, Chopei M, Sivolob A. Single nucleus versus single-cell gel electrophoresis: kinetics of DNA track formation. Electrophoresis. 2015;36(7-8):973-7.

28. Díaz-Martínez LA, Giménez-Abián JF, Clarke DJ. Chromosome cohesion - rings, knots, orcs and fellowship. $J$ Cell Sci. 2008;121(Pt 13):2107-14.
29. Peters JM, Tedeschi A, Schmitz J. The cohesin complex and its roles in chromosome biology. Genes Dev. 2008;22(22): 3089-114.

\section{Хроматин у стані фрактальної \\ глобули: підтвердження за допомогою \\ кометного електрофорезу}

К. С. Афанасьєва, М. І. Чопей, А. В. Сиволоб

В інтерфазному ядрі хроматин організований у вигляді петельних доменів, що виникають у результаті контактів між віддаленими локусами. Мета роботи полягала у дослідженні розподілу за довжиною петельних доменів ДНК у нуклеоїдах, отриманих шляхом лізису клітин або ізольованих ядер. Методи. Ми застосовували метод електрофорезу ДНК ізольованих клітин для аналізу кінетики міграції петель ДНК із двох типів нуклеоїдів. Результати. Кінетичні криві, що описують вихід ДНК із двох типів нуклеоїдів, відрізнялися декількома особливостями. У той самий час, в обох випадках кількість ДНК в електрофоретичному треку лінійно залежить від розміру найдовших петель у ньому. Висновки. Отримані результати свідчать, що для петель до $\sim 100 \mathrm{~kb}$ їхній розподіл за довжиною узгоджуються зі структурою фрактальної глобули.

К л ю ч о в і с л о в а: петельні домени ДНК, фрактальна глобула, кометний електрофорез, клітинні ядра.

\section{Хроматин в состоянии фрактальной глобулы: подтверждение при помощи кометного электрофореза}

\section{К. С. Афанасьева, М. И. Чопей, А. В. Сиволоб}

В интерфазном ядре хроматин организован в виде петельных доменов, возникающих в результате контактов между отдаленными локусами. Цель работы заключалась в исследовании распределения по длине петельных доменов ДНК в нуклеоидах, полученных путем лизиса клеток или изолированных ядер. Методы. Мы использовали электрофорез ДНК изолированных клеток для анализа кинетики миграции петель ДНК из двух типов нуклеоидов. Результаты. Кинетические кривые, описывающие выход ДНК из двух типов нуклеоидов, отличались рядом особенностей. В то же время, в обоих случаях количество ДНК в электрофоретическом треке линейно зависит от длины наибольших петель в нем. Выводы. Полученные результаты указывают, что для петель до $\sim 100 \mathrm{~kb}$ их распределение по длине согласуется со структурой фрактальной глобулы.

К л юч е в ы е с л ов а: петельные домены ДНК, фрактальная глобула, кометный электрофорез, клеточные ядра.

Received 12.01.2015 